\title{
Ценный источник истории Бреста
}

Брест в 1939-1941 ге.: документы и материаль, сост. А. Г. Карапузова [и др.]; гл. ред. Е. С. Розенблат, Брест 2012, сс. 246, [12] л. фот.

В рассматриваемом сборнике публикуются документы и материалы, хранящиеся в Государственном архиве Брестской области (ГАБО), посвященные истории города Бреста в период с сентября 1939 по июнь 1941 года. Данное издание, как замечают его составители, является логическим продолжением сборника «Брест в 1919-1939 гг.: документы и материалы»1.

1 См.: Monika Famielec, Источник разнообразной информачии о Бресте / Брест в 1919-1939 ге.: документы и материаль, сост. А. Г. Карапузова [и др.]; гл. ред. Е. С. Розенблат, Брест 2009, 308 с., [12] л. фот. [w:] "Białorutenistyka Białostocka", t. 2, Białystok 2010, s. 286-88. 
Авторам данного издания удалось изучить огромное количество разнообразных документов, восстанавливающих многоаспектность городской жизни в предвоенный период, и систематизировать их в сборнике. Так, например, из постановлений городского исполнительного комитета четко прослеживаются исторические реалии того времени: деятельность органов Временного управления в сентябре - ноябре 1939 года, партийного аппарата, милиции, общественно-политическая ситуация, первые мероприятия советской власти по перестройке всех отраслей жизни на советский лад (в том числе национализация частных предприятий и крупных домовладений, переименование улиц, создание советских учреждений), подготовка и проведение выборов в Народное Собрание Западной Беларуси и местные органы советской власти, состояние промышленности, торговли, здравоохранения, образования и др.

После сентябрьских событий 1939 года (нападение фашистской Германии на Польшу, переход Красной Армией советско-польской границы и вступление в Брест 22 сентября 1939 г.) территория Западной Белоруссии вошла в состав Белорусской Советской Социалистической Республики. С этого момента в истории как пограничного города, так и западных белорусских земель начался советский период. Согласно приказам советского командования во всех городах Западной Белоруссии создавались органы Временного управления, главная задача которых заключалась в том, чтобы возобновить деятельность всех предприятий и учреждений, обеспечивающих жизнедеятельность населения (в том числе магазинов, хлебопекарен, ресторанов, кинотеатров, банков); восстановить телеграфную сеть, электроосвещение и водоснабжение.

С установленем советской власти облик города Бреста стремительно менялся: начались активные работы по ликвидации последствий войны, ремонтировались тротуары и дороги, здания, а также понтонный мост через реку Мухавец. С улиц и строений исчезло все то, что непосредственно напоминало о недавней принадлежности города к Польше - польская национальная символика, портреты государственных деятелей, вывески на учреждениях. Завершением процесса советизации стало переименование улиц города (всего 129 линейных объектов ${ }^{2}$ ) и установление памятников погибшим во время боевых действий советским воинам. Новые названия в микротопонимии города отличались своей массовостью и последовательностью. Существовавшие до того времени имена, которые относились к истории и культуре Польши, напр., ул. Баторего, Бема, Зыгмунтовская, Костюшки, Нарутовича, Пилсудского, Реймонта, Траугута, Мичкевича, З-го Мая, уступили место обозначениям, отвечающим идеологии советской власти. В новой политической ситуации на карте Бреста появились урбанонимы, увековечивающие партийных и государственных деятелей: ул. С. М. Кирова, М. В. Фрунзе, Ф. Э. Дзержинского, В. Р. Менжинского, Н. К. Крупской, Г. К. Орджоникидзе, основоположников научного коммунизма: $K$. Маркса, Ф. Энгельса, В. И. Ленина, а также русских поэтов и писателей: Н. В. Гоголя, Л. Н. Толстого, Н. А. Островского,

2 Список переименованных в 1940 г. улиц г. Бреста, ГАБО, Ф.Р-273, оп. 1, д. 269, л. $1-3$. 
А. С. Пушкина, А. П. Чехова, И. С. Тургенева, М. А. Шолохова, М. Горького, М. Ю. Лермонтова.

Вследствие внезапного начала войны в июне 1941 года и немецкой оккупации, документы периода 1939-1941 гг. сохранились в госархиве Брестской области частично. Тем не менее, они дают представление о первых мероприятиях советской власти в западных областях, вошедших в состав БССР.

Основу анализируемого издания представляют документы, касающиеся деятельности Брестского обкома (протоколы заседаний бюро обкома, 1-й областной партийной конференции, пленумов обкома, информации о работе партийных организаций города и районов Брестской области) и горкома КП(б)Б (протоколы партийных собраний, планы и отчеты о работе парторганизаций, учреждений и предприятий города, списки первичных партийных организаций города, переписка с обкомами и райкомами), Кобринского временного управления, Брестского облисполкома и горисполкома. Кроме перечисленных документов, в работе были использованы материалы печатных изданий: областной газеты «Заря» и республиканской - «Советская Белоруссия» за 1940-1941 года.

В сборнике представлены, в основном, постановления и протоколы, а также распоряжения, указания, отчеты, информации, докладные записки, сообщения, сведения, объявления, списки и другие документы.

Рецензируемое издание состоит из трех тематических разделов, включающих в целом 142 актовых документа, на 197 страницах: 1. Общественно-политическая жизнь города (с. 10-85); 2. Экономика, городское хозяйство и благоустройство (с. 86-159); 3. Социально-культурное развитие города (с. 160-207). Нумерация документов валовая. Внутри каждого раздела и подраздела документы расположены в хронологическом порядке (исключение составляют документы № 90, 73 и 11). Фрагменты некоторых документов, содержащих сведения различной тематической направленности (напр., протоколы заседаний бюро обкома, облисполкома, горисполкома), опубликованы отдельными частями в соответствующих разделах сборника. Большая часть документов публикуется в полном объеме. В сокращенном виде подаются те документы, объем которых большой, а сведения либо не относятся к теме сборника и истории г. Бреста в описываемый период, либо не представляют интереса с точки зрения составителей. Пропуски текста отмечены предлогом «из» в заголовке, многоточием в квадратных скобках и оговорены в текстуальных примечаниях. Документы публикуюся на языке оригинала. Текст документов, в основном, передается с соблюдением правил современной орфографии и пунктуации (в отдельных случаях соблюдена орфография документов), с сохранением языковых и стилистических особенностей оригиналов. В документах на белорусском языке сохранено оригинальное правописание. Каждый документ снабжен редакционным заголовком, в котором указаны порядковый номер документа, его разновидность, автор, адресат, краткое содержание, дата документа, место написания и, при наличии, гриф секретности. В силу того, что практически все документы, включенные в сборник, созданы в г. Бресте, место написания документа указывается только в случае создания его в другом населенном пункте и приводится под редакционным заголовком слева. Все архивные материалы снабжены легендами, которые располагаются под текстом документа 
справа, в них указаны поисковые данные документа (номера фонда, описи, дела и листов), подлинность, способ воспроизведения и наличие предыдущих публикаций.

Научно-справочный аппарат издания состоит из: предисловия (с. 3-7), примечаний по тексту и содержанию документов, комментариев (с. 209-224), именного указателя (с. 225-231), списка сокращений (с. 232-237), перечня публикуемых документов (с. 238-243), перечня использованных источников (с. 244) и содержания (с. 245).

Ценность рецензируемой работе придают различного рода иллюстрации: фотографии председателей Брестского облисполкома и горисполкома, секртарей Брестского обкома в 1940 года, улиц Советской и Маяковского, мероприятий, проводимых в 1941 года в городе (напр., жители г. Бреста на первомайской демонстрации, работники артели «Красный кожевник», железнодорожники главных вагонных мастерских г. Бреста, самодеятельный танцевальный коллектив Дома народного творчества, исполняющий белорусский танец «Лявониха»), а также разнообразные объявления, публиковавшиеся в газете «Заря» за 1940-1941 годов, - например, о гастролях театров и репертуаре кинотеатров, о концертах, об открытии выставки детского творчества, лодочной станции «Динамо», о наборе в Брестское государственное музыкальное училище, информация о матче на стадионе «Спартак» и др.

Представленное издание авторы рекомендуют для ученых, историков, краеведов, а также для всех, кто интересуется историей города Бреста. Сборник является ценным источником весьма интересной и разнообразной информации, как исторической, так и лингвистической, о городе Бресте в предвоенный период.

Моника Фамелеи Бblдгош 